\begin{tabular}{ccc}
\hline & International Journal of Current Research in \\
Biosciences and Plant Biology & Volume 5 • Number 10 (October-2018) ・ ISSN: 2349-8080 (Online) \\
\hline EXCELLENT \\
PUBLISHERS
\end{tabular}

Original Research Article

doi: https://doi.org/10.20546/ijcrbp.2018.510.001

\title{
Anomalies Occurring in Allium L. Species by the Effect of Environmental Conditions
}

\author{
S. R. Hasanov* and Z. İ. Akparov \\ Genetic Resources Institute of ANAS, Azadlıq Ave., 155, Baku AZ 1106, Azerbaijan \\ *Corresponding author.
}

\begin{tabular}{|c|c|}
\hline Article Info & ABSTRACT \\
\hline $\begin{array}{l}\text { Date of Publication: } \\
\text { 06 October } 2018\end{array}$ & \multirow{3}{*}{$\begin{array}{l}\text { Various anomalies occurring in the generative and vegetative organs have been } \\
\text { recorded due to the environmental factors during both the agro-cultivated introduction } \\
\text { and in natural areas of Allium L. species in the territory of the Republic of Azerbaijan. } \\
\text { In the environmentally-friendly environment, it was also observed the bulbils in the } \\
\text { flowering umbels of some species of A. waldsteinii Don. Anomalies, such as facsiation (a } \\
\text { malformation of plant stems commonly manifested as enlargement and flattening as if } \\
\text { several stems were fused), deformation (change of shape), and prolification } \\
\text { (replacement of one organ with other) in the structural elements of the flowers of } \\
\text { agriculturally introduced varieties (A. waldsteinii Don., A. erubescens C. Koch, A. } \\
\text { fuscoviolaceum Fom., A. viride Grossh.) have occurred. Prolification occurred in the } \\
\text { onion bulb (A. cepa L.) in the local Khachmaz type, the bulbil germination in umbel in } \\
\text { the local Jalilabad variety of garlic (A. sativum L.) has been recorded. }\end{array}$} \\
\hline Keywords & \\
\hline $\begin{array}{l}\text { Anomaly } \\
\text { Deformation } \\
\text { Fasciation } \\
\text { Generative } \\
\text { Prolification } \\
\text { Vegetative }\end{array}$ & \\
\hline
\end{tabular}

\section{Introduction}

Allium L. genus of the family Amaryllidaceae are distributed in mountain slopes, stony-gravel areas, well-lit areas of forests, forest fronts, sown areas, permanent humid sites, various biocenoses and deserts of Azerbaijan (Flora of Azerbaijan, 1952; Bullets of Caucasus Flora, 2006). 72 species of Allium L. spread throughout the northern hemisphere 52 in the Caucasus and 52 of them spread in Azerbaijan. Here, the onions are found in areas at an altitude of 50-3500 $\mathrm{m}$ above sea level
(Ibadli, 2002). All species spread in Azerbaijan are esculent (Aliyev, 1997).

In recent years, the strengthening of anthropogenic impact threatened onion plant species not only in populated areas, but even in remote areas, and there was a problem of their conservation and rational use (Danilov and Kotukhov, 2006; Shisha et al., 2008)

Researchers show that it is not possible to prepare scientific basis for their effective use and protection without thoroughly studying the bio-ecological 
characteristics of crops (Shisha et al., 2008). Study of adaptive properties of onions in both in natural and adjacent conditions makes the basis for their protection and effective use (Hasanov and Shikhlinski, 2017). In order to ensure efficient use of crops and their safe protection, their agroculturally introduction is preferable, changes in biomorphological signs and adaptive ability of crops to new conditions is studied (Tukhvatulina, 2002; Yusupov and Vahabov, 2014; Hasanov et al., 2017).

In the study of wild onion species in natural areas, along plants with normal signs the plants with abnormal signs are also found (Bulakh, 1984; Danilov and Kotuhov, 2006). Researchers have shown that onion varieties are characterized by anomalies in flower umbels and flower crowns under their introduced and natural spread conditions (Ustinova, 1953; Filimonova, 1963; Mirkamilov and Philipanova, 1973; Kudutyashova, 2008). Bulakh (1984) recorded anomalies in 20 forms of their flowers on the wild onions in natural ecological conditions. More anomalies have occurred in the perianth, then androecia and gynoecia. A. karataviense, A. barsczewskii and A. kokanicum species more anomalies were observed, and in A. caesicum and A. fedtschenkoanum species have observed relatively few anomalies.

Researchers show that changes in environmental conditions affect plant species negatively, such as anomalies as fasciation, deformation (change of shape) and proliferation (replacement of one organ with other) (Kotukhov, 1979; Danilov and Kotukhov, 2006). From the literature, it is known that anomalies occur not only in generative organs of the onions, but also in their vegetative organs (Philimonova, 1970; Hasanov, 2012).

\section{Materials and methods}

The materials of the research work were varieties of Allium L. and varieties of cultivated species in Azerbaijan. In this regard, research has been carried out in different regions of Azerbaijan. Field experimental work was carried out at Absheron scientific research base of the Genetic Resources Institute of ANAS. During the research, phenological observations (Methodological Phenology Observations, 1966) and commonly accepted field geobotanical methods were used (Methodology of Field Geobotanical Research, 1938).

The introduction of plants was carried out by accepted methods in both bulbs and seeds (Hayretdinov, 1983; Rusanov, 1950; Titova, 1978).

\section{Results and discussion}

In A. waldsteinii Don, spread over $1630 \mathrm{~m}$ from the sea level at the Zuvand hollow of the Talysh mountains in Azerbaijan, along with the seeds it was observed the bulbils (prolification) in umbels. In the flower umbrella of the species, it was observed that seeds of air were formed along with seeds (prolification). Their number was about 1-3 in umbel. The diameter of so bulbils is larger than normal, sometimes up to $1 \mathrm{~cm}$. Bulbils are usually sprouted in the crown and form root. When the flower shoot lies on the ground, the contact between the sprouted bulbils and the soil develops, their roots are rapidly growing and form new plants.

It is known from the research that due to changes in the rhythm of the seasons during the introduction, there is a breakdown in the morphogenesis of plants, which causes changes in vegetative and generative organs of plants.

The anomalies, as fasciation, deformation and proliferation in the structure of the flora of the species introduced in agronomic conditions in the Absheron region (A. waldsteinii Don, A. erubescens C.Koch., A. fuscoviolaceum Fom., A. viride Grossh.), from different ecological conditions in separate years, were recorded. It has been determined that the anomalies in the flowers do not affect the overall development of the plants. In the plants of introduced species, more fasciation cases were recorded. Onions have two forms of fasciation, linear (full fasciation) and radial (partial 
fasciation) forms. Full line fasciation occurs when 2-5, and rarely 7 flowers are fully interconnected. Fruit boxes that have formed from these flowers are also conjoined to each other. Changes in the number of flower elements (petals and stamens) occur during linear fasciation.

During radial fasciation, flower stalks are not fully formed, but are interconnected by certain parts. In this case 2-3, rarely 5 flower saplings are interconnected with certain parts. In radial fasciation also occur changes in the number of flower elements, as in linear fasciation. During the introduction, the deformation of onion species has been observed in the general structure of flowers and their separate elements. In some cases, flowers become flat and get disfigured. Deformation of the perianth is observed by changing of the number of organs, their view and location. Flower umbels are also found in flowers that have no stamens, and the pistil is quite normal.

Another anomaly form is conjoining of certain parts of flower stalks. At this time 1/2, 2/3 part of flower stalks is conjoined. In deformed flowers, the number of ovarian cells sometimes ranges from 1 to
5. More than 4 ovary cavities are found in such flowers. In introduced $A$. viride Grossh. species of secondary umbel appearance occurred. The second umbel has been developed from inside a flower umbel of a plant, and from the side of umbel develops the second umbel covered with umbel cover. There were 12-17 normal developed flowers in such umbels. In some of plants of A. waldsteinii Don. introduced into the Absheron environment, along the seeds were also recorded the formation of 1-3 bulbils (prolification). Researches, carried out during the introduction of onions, show that the changes in the rhythms of the seasons cause some changes in the morphogenesis of plants, which is reflected in their vegetative and generic organs.

The hot weather conditions in 2016 caused anomaly in some plants of the local Khachmaz bulb variety (A. cepa L.), planted to get seeds. In these plants, instead of seeds, the bulbils were formed (prolification), and they were sprouted in the umbel (Fig. 1).

In 2016, (A. sativum L.) the bulbils in the floral crown, were sprouted in the floral crowns of the garlic local Jalilabad variety (Fig. 2).



Fig. 1: Bulbils sprouted in the crown (A. cepa L.) 


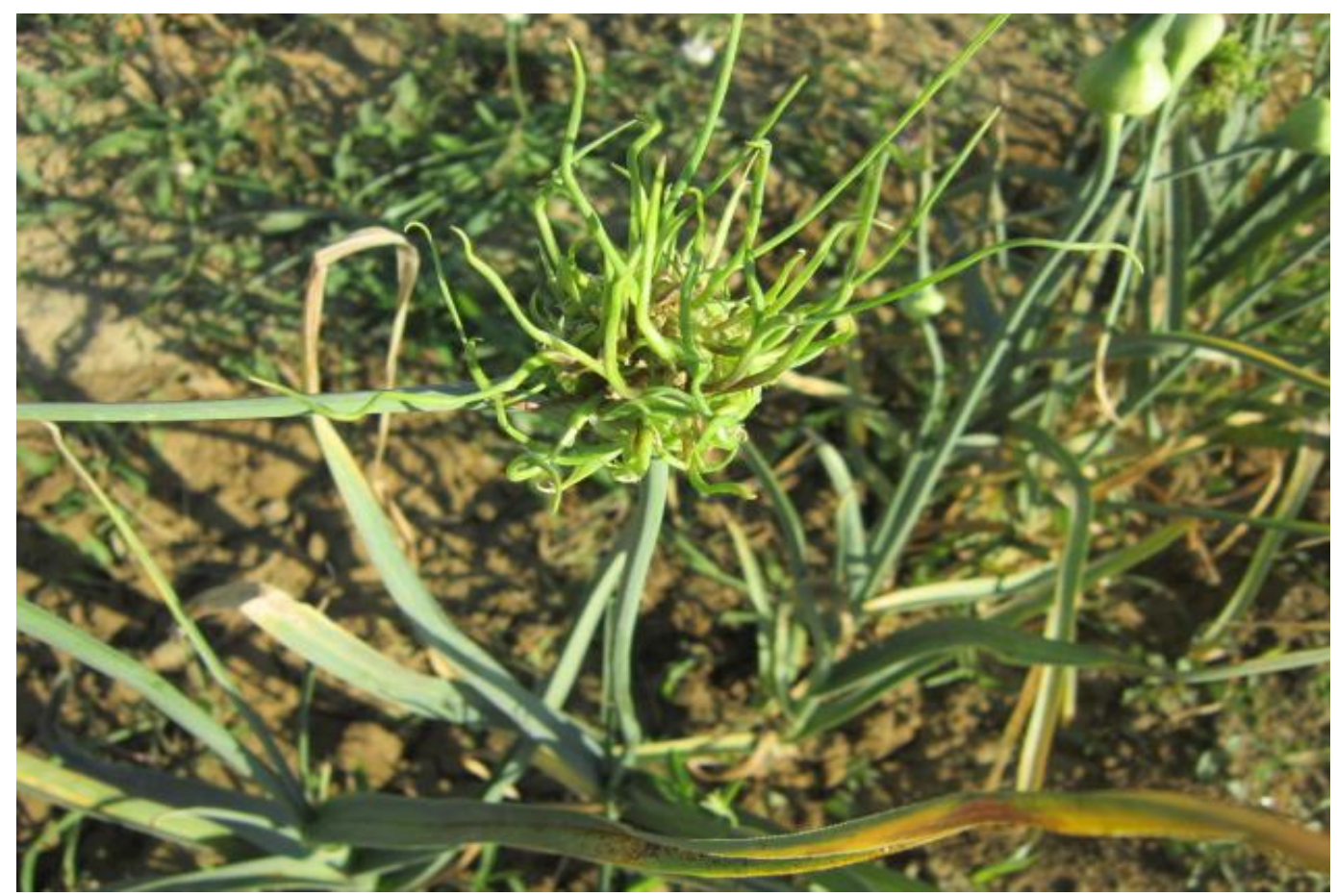

Fig. 2: Bulbils sprouted in the crown of garlic (A. sativum L.)

Abnormal shoots and bulbils have been formed in Luxembourg variety form of the non-shoot developing garlic plants, which were introduced to the Absheron region in 2016. There is also anomalies in the structure of the pistils and their arrangement in bulb of this variety form (Fig. 3).

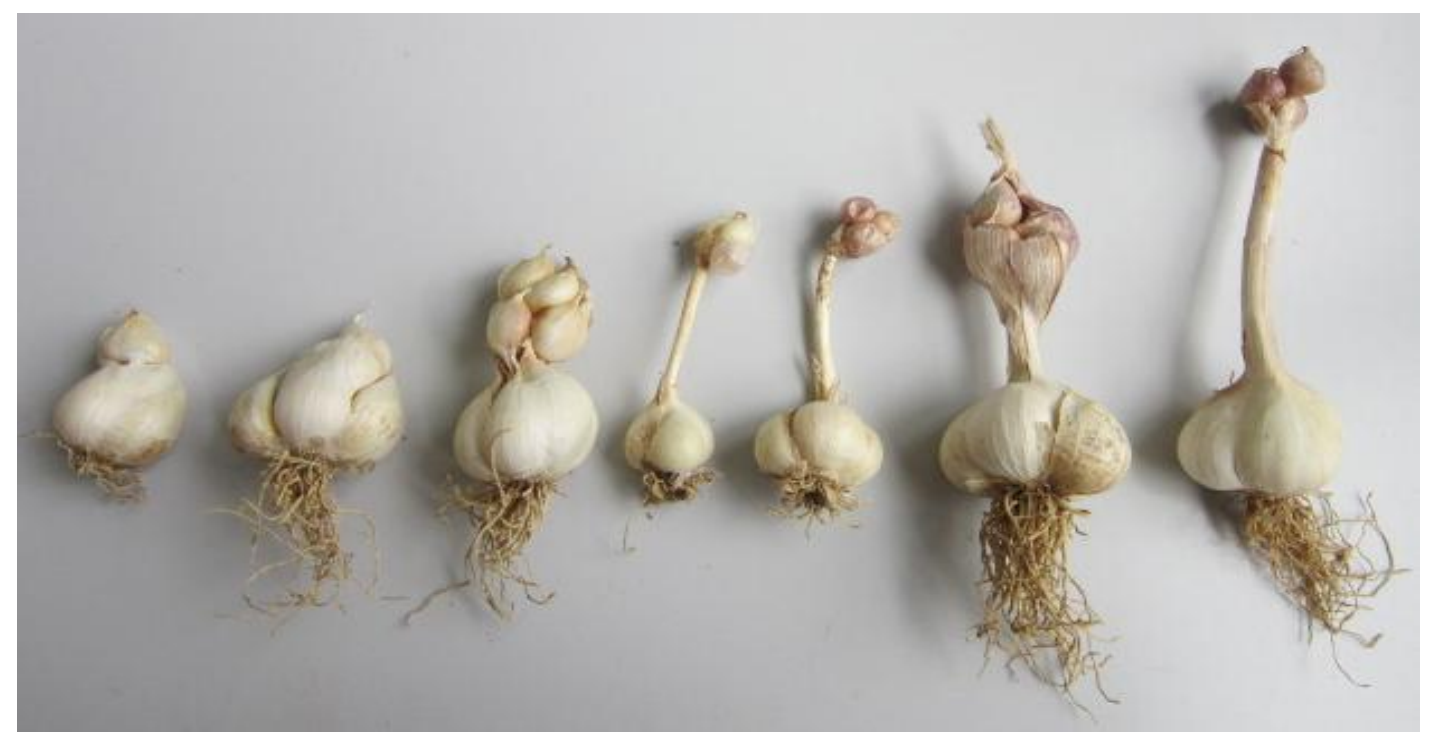

Fig. 3: Anomalies occurred in bulbs and shoots of garlic (A.sativum L.)

Anomalies have also occurred in the vegetative organs of wild onions due to the external environment. Thus, in some of the A. vineale $\mathrm{L}$. species introduced to the cultivated species, the output of abnormally developed large bulbils by exploding the stem have been recorded (Fig. 4).

Practice shows that ecological conditions cause anomalia in both the generative and vegetative organs of the Allium species. 


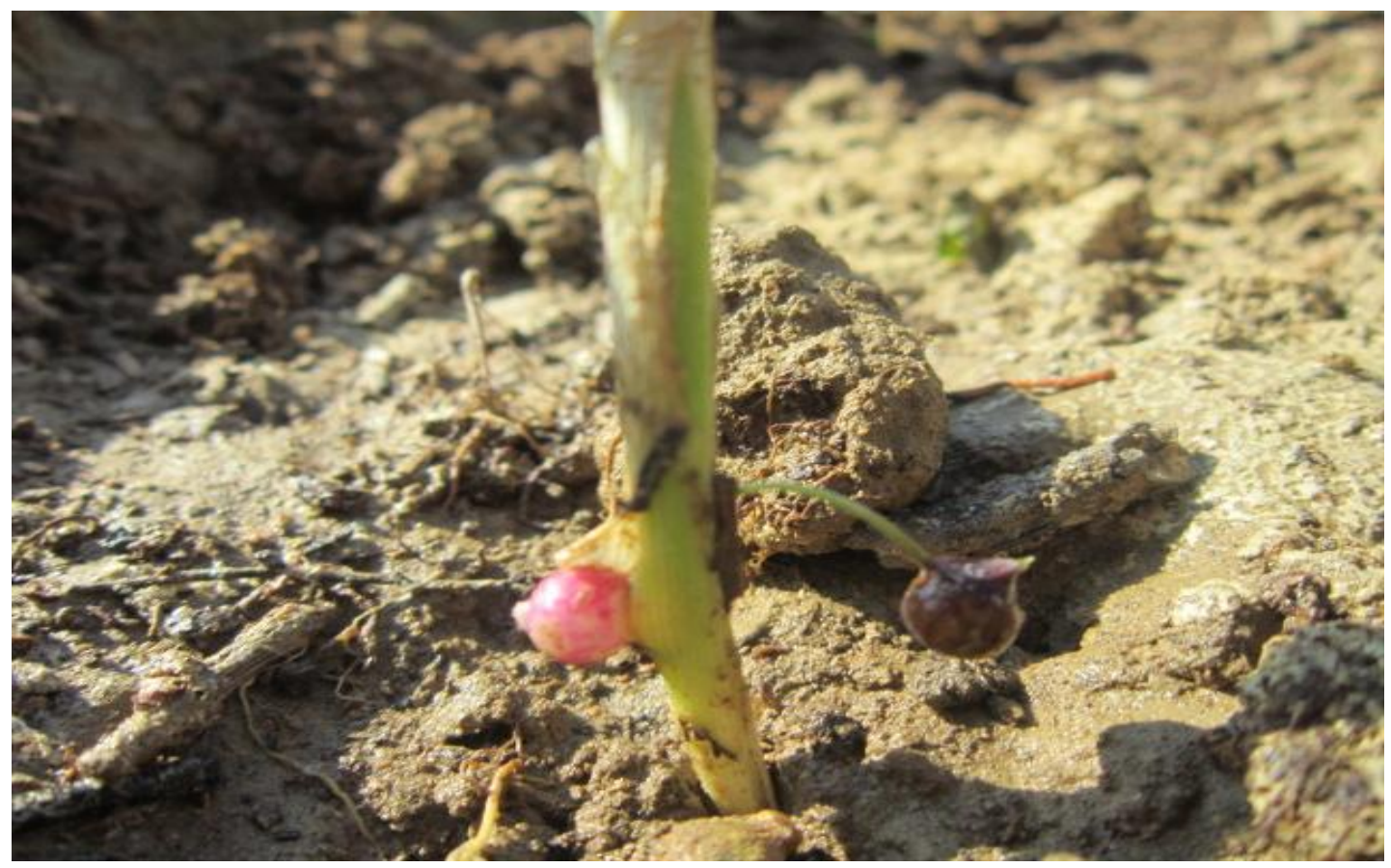

Fig. 4: The output of bulbils by exploding of stem in A.vineale L.

\section{Conflict of interest statement}

Authors declare that they have no conflict of interest.

\section{References}

Aliyev, Ş. A., 1997. Vegetable-growing. Baku, BSU. pp.190-195.

Bulakh, P. E., 1984. Ecological-biological features of species Allium L. of Central Asia flora in connection with their introduction in Ukraine. Dis. Cand. Biol. Sciences: Kiev. 249p.

Danilov, A. N., Kotukhov, Yu. A., 2006. Ecological and biological features onion, Altai (Allium altaicum Pall.) in the natural conditions of southern Altai and during introduction in the Altai Botanical Gardens. Reports National Academy of Sciences, Republic of Kazakhstan. \# 2, pp.96-100. Abstract of the Flora of the Caucasus, 2006. Petersburg: St. Petersburg State University, E.11. pp.140-159.

Filimonova, Z. N., 1963. Some data on the development and structure of inflorescences in species of the genus Allium L. In: Introduction and Acclimatization Plants. Вып.2, Ташкент, Фан. pp.47-54.
Filimonova, Z. N., 1970. Changes in the structure of bulbs in ontogenesis in species of the genus Allium L. of the Molium Don section. In: Introduction and Acclimatization Plants. Вып.6, Ташкент, Фан. pp.153-163.

Flora of Azerbaijan, 1952. Baku: AN Az. SSR, II. pp.134-162.

Hasanov, S. R., 2012. Changes in garlic plant (Allium sativum L.) occurred by influence of drought and warmth stress factors // ANAS News (biol.və tibb elmləri), 67(3), 85-88.

Hasanov, S. R., Shikhlinski, H. M., 2017. Features of the biology of flowering and fruiting of individual wild species of the genus Allium L. at introduction. World J. Pharm. Pharmaceut. Sci. 6(5), 32-39.

Hasanov, S. R., Shikhlinski, H. M., Namazova, Ch. T., Huseynzade, G. A., 2017. Introduction of wild onion A. fuscoviolaceum Fom and A.mariae E. Bordz to naturalization. World J. Pharm. Pharmaceut. Sci. 6(6), 373-377.

İbadl1, O.V., 2002. Geofits of Caucasus. Baku. pp.28-40.

Khayretdinov, S. S., 1983. Introduction wild onions in Bashkiria. In: Resources and Introduction of Plants in Bashkortostan: Sat. Sci. Tr. Ufa. 
pp.96-104.

Kotukhov, Yu. A., 1979. Anomalies of onions in Kazakhstan. Bull. Acad. Sci. USSR. III, 49-53.

Kuduryashova, G. L., 2008. Morphological biological features of the inflorescence of species of the genus Allium (Alliaceae). Botanic. J. 93(2), 270-280.

Methodology of Field Geobotanical Research, 1938. ML, AN SSSR: 214 Methods of Phenological Observations in Botanical Research (1966), L. Science. 152p.

Mirkamilov, M. A., Filimonova, Z. N., 1973. Anomalies in the structure of the inflorescence flowers of species of the genus Allium, section Mollium Don in the conditions of Tashkent. In: Introduction and Acclimatization of Plants. Issue. 10, Tashkent. pp.138-140.

Rusanov, F. N., 1950. New methods of introduction of plants. Bull. Gl. Bot. Garden, 7, 86-88.

Shisha, E., Sikura, I., Kuchuk, N., 2008. In vitro conservation of biodiversity species of the genus Allium L. Scient. Bull. Uzhgorod Univ.: Biol. 24, 244-254.

Titova, O. A., 1978. Introduction some rare and endangered species of the genus Allium L. in Tashkent. In: Introduction and Acclimatization of Plants. No. 15, Tashkent. pp.65-71.

Tukhvatulina, L. A., 2002. Some features of the biology of representatives of the genus Allium L. upon introduction into Botanical Garden of the City of Ufa. Role of Botanical Gardens in Conservation Biodiversity. Rostov-on-Don State University. pp.236-238.

Ustinova, E. I., 1953. Anomalies in structure of flowers in bows. Botan. J. 38, 150-156

Yusupov, Yu., Vakhabov, M., 2014. Introduction of wild onion Karatav in culture. News of Academy of Sciences, Tadzhikistan Branch Biological and Medical Sciences. №2 (186). Dushanbe. pp.15-18.

\section{How to cite this article:}

Hasanov, S. R., Akparov, Z. İ., 2018. Anomalies occurring in Allium L. species by the effect of environmental conditions. Int. J. Curr. Res. Biosci. Plant Biol. 5(10), 1-6.

doi: https://doi.org/10.20546/ijcrbp.2018.510.001 